\title{
How does street trading activities keep Chinatown in Kuala Lumpur a living cultural enclave?
}

\author{
Angelyn Tan 'G'-Ling ${ }^{1 *}$, Asrul Aminuddin ${ }^{2}$ \\ ${ }^{1,2}$ Department of Architecture, Faculty of Built Environment, University of Malaya \\ *angelyntan.msia@gmail.com
}

Received: $8^{\text {th }}$ August $2018 \quad$ Final version received:26 ${ }^{\text {th }}$ December 2019

This study aims to discover the factors that contribute to the continued success of street trading activities in Chinatown Kuala Lumpur and investigate how these informal economies remains relevant in a modern city. The street trading activities have sustained the place as a living cultural enclave through the robustness of street activities, high pedestrian traffic and the attractive street life experience. The objectives of this study is to find the success factors of the site as a guideline for streets to remain active public spaces and for similar cultural enclaves to be allowed to thrive as living heritage of a city. The mixed method approach through site observation and census-like survey captured an all-inclusive reading of the tangible and intangible aspects of the site. Based on the findings of this research, six emerging characteristics of the street trading activities were identified: high concentration of business activities, variety of choices, availability of food, lively outdoor atmosphere, promotes street walkability and extended business hours. This paper serves to offer a new perspective on sustainable urban planning approaches especially in parts of old city quarters as wells as cultural or ethnic enclaves where the organic place making, some haphazardness and a sustainable living community are recognised and celebrated as exciting characters in the urban fabric of the city.

Keywords: Street Trading, Urban Public Spaces, Cultural Enclave, Street Life, Chinatown

\section{INTRODUCTION}

Traditional shopping streets in Malaysia were central in the daily lives of the urban populace, this is also true of many towns and cities in Southeast Asia. These traditional streets acted not only as a route for communication and transportation but along its linear pathway, businesses flourished as the daily activities and lives of the townspeople thrived. In most developing nations, such public spaces - along the main streets or at pocket spaces dotting it, a myriad of informal economies such as street peddling or street hawking can be found. In an earlier study on shopping streets in the older quarters of Kuala Lumpur, Shuhana Shamsuddin (2008) observed that streets such as Jalan Petaling in Chinatown, Jalan Tuanku Abdul Rahman and Jalan Masjid India continue to be living examples of traditional shopping streets which have stood the test of time. The research also proves that this particular organization and street use differs from that of Western urbanism where the piazzas and plazas were the nucleus of the town center.
As Malaysia embraces the systematic urban development to be on par with other world class cities, the traditional shopping streets faces a slow death contributed mainly by insensitive urban planning, the disappearance of the traditional shophouses as well as poor succession of family run business legacies. To make matters worse, the construction of large corporate offices, one stop commercial centers and shopping malls in place of traditional shopping streets further pushes the irrelevance of street trading activities in a modern city (Shuhana Shamsuddin \& Sulaiman, 2001).

In spite of the challenges and changes in attitude, the informal economies particularly that of Chinatown Kuala Lumpur remains sustainable, relevant and attractive. In addition to this, the Street Market which continues to attract high pedestrian traffic flow, both from the local community as well as tourist alike also contributes significantly to the robustness of the street life in the city. This study seeks to identify the success factors contributing to active street life in Chinatown Kuala Lumpur for future city 
renewal programmes. The study draws its conclusion from observing the daily operations of the street trading activities as well as the use of the physical environment as a setting for these informal economies. It is the desire of the study that the immerging findings serve as a guideline to ensure that similar spaces continue to thrive as a living heritage of the city and for future development projects to adopt these success factors. This research however chooses not to deliberate on the element of authenticity in observing the characteristics of the street trading activities.

\section{LITERATURE REVIEW}

\subsection{The Informal Economy and Street Trading Activities}

The definitions of 'street trader', 'street vendor' or 'street hawker' refers to a group of entrepreneurs who are involved in the informal peddling of goods and services at the street level or in public open spaces. These businesses can operate from rudimentary structures, mobile pushcarts, back of vehicles or even being peddled on foot. The different types of goods that are being peddled are limitless and can range from vegetables, fruits, clothing, toys, antiques, street food or even some forms of services such as the street cobbler (Bhowmik, 2007; J. C. Cross, 2000)

Bromley (2000) opines that the street trading activities not only adds vitality to the streetscape and encourage pedestrian traffic but also can contribute to the economic activities and livelihoods of the traders as well as a service provision for the city dwellers.

The modern formal economy may view businesses related to street trading activities as being 'backwards' or 'traditional' and is to undergo a systematic eradication from the modern city streets. Some authors have also argued that street peddling are 'disorderly' and 'unnecessary' for cities in the current age as they contribute to clutter, noise, interruption to traffic flow and post health threats due to the lack of sanitation and hygiene especially that of street food hawkers (Packard, 2014; Lyon, 2007; G. Bromley, 2007; Sun, Bell, \& Scott; 2016) . According to Alderslade, Talmage, \& Freeman (2006) , such sentiments has resulted in 'cleaning up' and clamping down of such informal economies in certain countries. However, other authors argue that street trading activities will remain relevant in contemporary city living and will continue to be an 'extensive phenomenon' which has to be wisely dealt with (Bhowmik, 2007; J. C. Cross, 2000).

According to Recio \& Gomez (2013), the informal economy of street trading still remains relevant, vibrant and robust in many Southeast Asian cities. Malaysia is a forerunner in integrating key urban dimensions and establishing guidelines to allow such informal economies to thrive in the urban dimensions of her cities (McGee \& Yeung, 1977). More city councils around the world have also began to have a shift in paradigm regarding street trading and realize that there needs to be an integration of key urban dimensions for the economic sustainability of the informal urban sector (Chakrabarty, 2001). The study of marketplaces in Dhaka found that the provision of proper footpath and well-designed spatial organization through the street marketplace strongly influences the physical qualities of the environment. Pedestrians also reported an overall sense of enjoyment as they leisurely explore the marketplace in the city centre (Israt \& Adam, 2017).

\subsection{The Streets in a South East Asian City}

Streets and sidewalks have been described by Jacobs (1961) as the most vital organs of the city as they are the broadest shared public domain which gives character and identity to a place. According to Appleyard (1981), the usage of streets in a developing country is more complex than that in a developed nation.

In South East Asia, the use of streets easily transcend that for movement and transportation as they become a platform that support business and other socio-economic functions. Examples of the multi-faceted life on the streets are as gathering places for informal meetings, informal living and dining spaces (Oranratmanee, 2012). The use of streets as public meeting space was described as Oldenburg (1989) as the 'Third Place' after home and work where city dwellers are at ease to spend their time leisurely during the day or after work. Douglass \& Deniere (2000) describes the street life as being informal, spontaneous and temporal and therefore more intensive and exciting as compared to the street use in the Western perspective. 
Oranratmanee \& Sachakul's (2014) study on the characteristics and roles of these streets reveals a dynamic relationship between the streets and city dwellers whose lives are lived and displayed there. The author recommends the need for South East Asian street use be further studied as there are still limited information on this topic despite the elaborate and complex street use.

\subsection{Traditional Shopping Streets in Malaysia}

The urbanisation pattern of old towns and cities in Malaysia flourishes along the traditional shopping streets and thus forming the city's character and identity (Shuhana Shamsuddin, 2011). The definitive characteristics of a 'traditional shopping street' in the Malaysian context is one where business activities determine the operations, movements and behaviours of the street use. These business activities can take place formally from within the shophouses fronting the streets or from the informal settings along the five-foot arcaded walkways and at the street level itself. In Kuala Lumpur, the vibrancy, liveliness and robustness of such business streets such as that in Chinatown continues to remain relevant and appeals to the visitors (Shuhana Shamsuddin, 2011; Shuhana Shamsuddin \& Ujang, 2008; S. Shamsuddin, Sulaiman, Norhaslina, \& Maslyana, 2004)

In addition to shopping, the traditional business streets in Malaysia is also a place for social interactions by being engaged in the layering of visual and sensory stimulus, bargaining and haggling, catching up with friends or acquaintances, stopping by the street hawker for a quick meal as well as a place to wait while the services of the street cobbler or any such services are being sought. The covered arcaded walkways found at the ground floor of the shophouses also provides pedestrians a shaded resting place or shelter from rain (Shuhana Shamsuddin, 2011).

\subsection{Ethnic and Cultural Enclaves}

Up to 1889, the British administration had relocated the Malay community to Kampung Baru while the Chinese who were well adapted to urban life continued to live in town. The Chinese were instrumental in the urbanisation of the town, engaging in trade and establishing various cultural institutions forming a seemingly Chinese only settlement liken to a Chinatown (Loo, 2013).
In the context of multi ethnic modern day Kuala Lumpur, Chinatown can be described as an ethnic and cultural enclave for the Chinese community. In the book A Pattern Language, such enclaves were described by Alexander et al. (1977) as important components of a good city as separate spaces were formed for different subcultures to co-exist in harmony. He further stresses the importance of cities to be a 'mosaic of subcultures' where familiar lifestyle, customs and practices of a particular community can be freely demonstrated in a safe and comfortable environment.

\subsection{Street Trading Activities of Chinatown for Kuala Lumpur Livability}

The main character and identity of the streets in Chinatown today is that of a Street Market where street trading activities dominates the public space use. This continues to reflect its role as a traditional shopping street. Although much has changed in terms of its authenticity demographics, types of goods and the changing businesses ownership, Chinatown is still being recognised as an important cultural and ethnic enclave for the Chinese community in Kuala Lumpur.

In Social Life of Small Urban Spaces, Whyte (1980) identified a few key factors that influences the social life of urban spaces. Chinatown Kuala Lumpur strongly displays three of these key factors - firstly, having connection to the street seen through the active and robust street life. Secondly, is the availability of food especially street food which are economical and in a large variety and thirdly, as having the presence of street characters such as food preparation on site or florist working on their flower arrangements. The presence of street characters will attract the people to linger longer on the public streets to observe these activities and stimulates conversation between strangers. A livable city is one that provides such places for the city dweller to find a nourishing environment and build a meaningful connection with the city. This study seeks to uncover the characteristics that sustains the informal economy of street trading activities and how it contributes to the livability of Kuala Lumpur. 


\section{RESEARCH METHODO: MIXED METHOD APPROACH}

The mixed method approach was deemed as the most suitable manner to approach this study as it allowed for the research outcomes to be derived from both the tangible and intangible site observations. Research was conducted in two consecutive phases: Phase 1 Preliminary Site Investigations (qualitative) and Phase 2: Questionnaire Survey (quantitative).

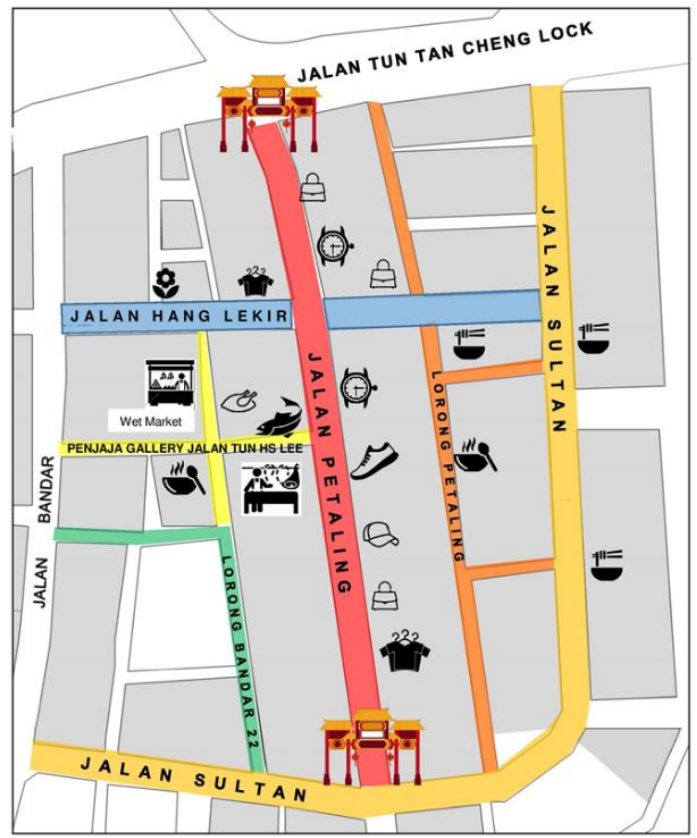

Figure 1: The case study area consists of streets and alleys where street trading activities can be found. The Street Market on Jalan Petaling and Jalan Hang Lekir are now being referred to by tourism websites and materials as 'Chinatown'.

The case study area is located in an area of about 12.8 hectares, bounded by Jalan Tun Tan Cheng Lock, Jalan Sultan up to the banks of the Klang River. The site is located within the first Chinese settlement in Kuala Lumpur which was first established in 1857. The diagram in Figure 1 shows the case study area with the indication of the various types of goods and merchandise found along the streets. In the oldest quarters of Kuala Lumpur, the narrow two lane streets are lined by rows of pre-World War II shophouses and newer buildings built over the original plots. There are many pocket spaces and back alleys which are being occupied by street trading activities and as pedestrian walkways. The respondents of the study consists of every street trader found at site regardless of the type of business activity, ownership status or nationality

\subsection{Phase 1: Preliminary Site Investigation (qualitative)}

The method used in the first phase of data collection is direct observation of the site where the researcher is a non-participant. The field study approach was selected in observing and recording the events and interaction that takes place in its 'natural setting'. Time sampling method was employed with the observations conducted throughout the duration of the business hours from $7 \mathrm{am}$ to $11 \mathrm{pm}$, during which human interactions, business processes, movements and changes of the street use can be clearly documented.

The observations are recorded in field notes with the reference to a checklist and reported in the form of descriptions, sketches and photographs. The checklist was instrumented based on the 'golden triad' of Farrell \& Hart (1998) which identifies communities based on the components of environment, economy and society as well as the instruments in the cultural mapping of Campbell Street market by Pillai (2013).

The researcher spent most of the day taking notes of the site and unfolding activities by walking, observing and people watching while being fully immersed and aware of the surroundings.

The preliminary site investigation informs the development, approach and implementation of the subsequent phase of data collection.

\subsection{Phase 1: Questionnaire Survey (quantitative)}

The data collection process in Phase 2 was conducted over the consecutive period of four days and every street trading activity within the case study area have been accounted for in a through census-like exercise.

The questionnaire survey form is a standard set of 44 questions which seeks to record the physical environment where street trading activities are found, types of items or services, background of businesses establishment, operational hours, demographics of the traders and clientele profile. The survey also seeks to identify the traders' attitudes and perception on the cultural values of street trading. 
The questions are close ended with a list of answers provided to facilitate the choice of answers. However, the respondents are still given the freedom to provide other answers that would better ensure the accuracy of the data.

The two units of analysis are: street trading activities and physical environment. These have been identified based on the analysis of Phase 1 .

The analysis is done using basic descriptive statistics and reported in frequencies and percentages. Cross tabulation was also used to analyse the findings based on activity type and the nationality of the trader, these two components also acted as the independent variables in the analysis.

\section{RESULTS AND DISCUSSION}

The primary findings of this research has been obtained from the qualitative findings from direct site observation as well as photographic records and then reinforced with quantitative data from the Questionnaire Survey.

Realising that there is a possible shortfall in explaining the phenomena at site through quantitative data solely, (Chua, 2012; Bogdan \& Biklen, 1992; Maxwell, 2012) suggests that primary data from both the site observation and survey should be collectively synthesised for the validity of emerging themes from the findings. Based on the findings of this research, six emerging and distinct characteristics of the street trading activities in Chinatown Kuala Lumpur were identified:

$\begin{aligned} \text { i. } & \text { High concentration of business } \\ \text { activities } & \\ \text { ii. } & \text { Variety of choices } \\ \text { iii. } & \text { Availability of food } \\ \text { iv. } & \text { Lively outdoor atmosphere } \\ \text { v. } & \text { Promotes street walkability } \\ \text { vi. } & \text { Extended business hours }\end{aligned}$

It is important for these characteristics to be recognized so that they can be emulated in further efforts to revitalize robust street life, revive older city quarters and protect the cultural or ethnic enclaves within a multicultural city.

\subsection{High Concentration of Business Activities}

The research identified a total of 547 street trading activities found in and around Chinatown Kuala Lumpur in the following breakdown of activity type: retail; 419 (77\%), food \& beverage (F\&B); 120 (22\%) and services; 8 (1\%).

From this number, 514 businesses were concentrated at six locations which include the Street Market on Jalan Petaling (338) and Jalan Hang Lekir (76) as well as Jalan Sultan (46), Lorong Petaling (17), Penjaja Gallery Jalan Tun H.S.Lee (26) and Lorong Bandar 22 (11) all of which are 'spill over spaces' physically accessible from Street Market. The Street Market on Jalan Petaling and Jalan Hang Lekir are popularly regarded today as 'Kuala Lumpur's Chinatown'.

There are four settings where street trading activities can be found - pavement; 243 (44\%), main street; 200 (37\%), back alley; $70(13 \%)$ and five foot way; $34(6 \%)$. The diagram in Figure 2 illustrates the location of each of the setting mentioned and demonstrates the robustness of the street atmosphere with the layering of activities and variety of things to experience through the depth of interaction between the users and the space.

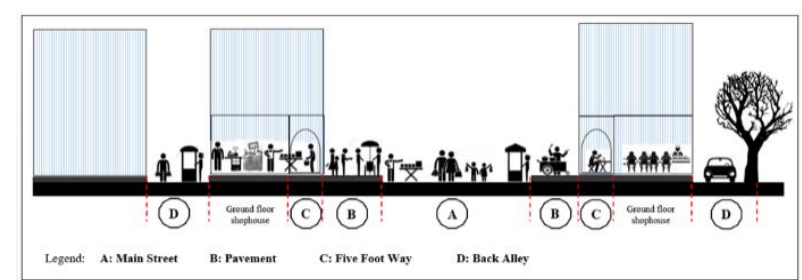

Figure 2: Settings for street trading activities in Chinatown Kuala Lumpur

The retail activity type operates mainly from the pavement;190 (45.6\%) and the main street; 174 $(41.7 \%)$ while the remaining are the back alley;28 (6.7\%) and $25(6 \%)$ at the five foot way. The food \& beverage (F\&B) businesses also takes advantage of the visibility and strategic setting of the pavement where $51(41.8 \%)$ are situated there. There are $42(34.4 \%)$ operating from the back alleys, $24(19.7 \%)$ main street and $5(4.1 \%)$ five-foot way. It is clear that $60 \%$ of all street trading activities found in the back alleys are related to food hawking and thus making these narrow alleys a place to dine in Chinatown. 
The compilation of photographs in Figure 3 and Figure 4 shows examples of the premise types and structures categorised under two general groups - permanent and non - permanent type structures.

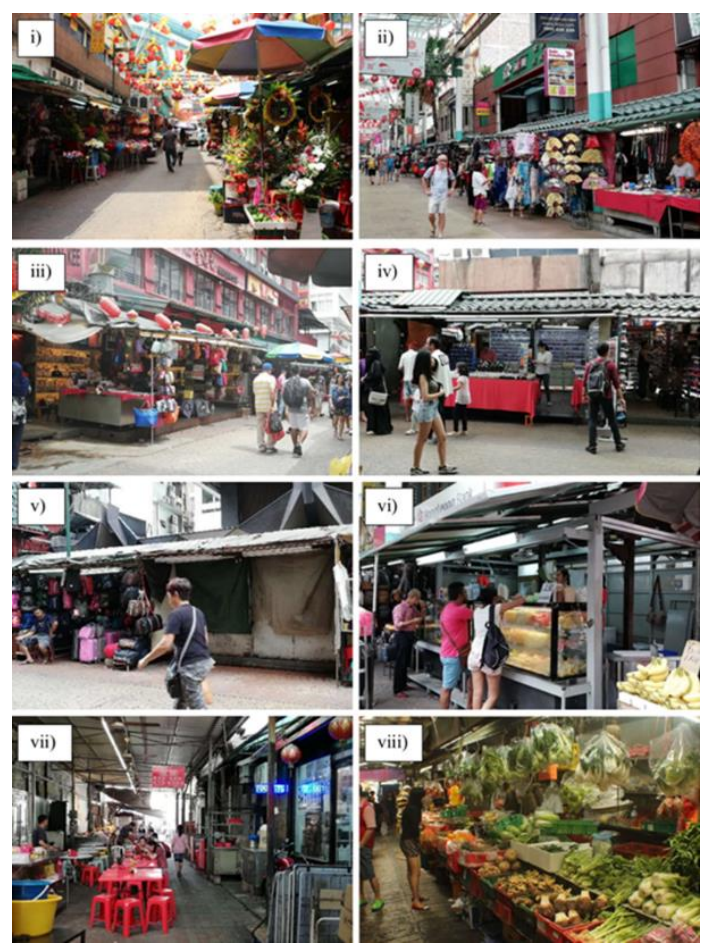

Figure 3: Examples of permanent structures in Chinatown Kuala Lumpur

(i) Florists operating from standardized metal boxes acts as 'shops' that are located on the pavements of Jalan Hang Lekir,(ii) The green roofing constructed on pavements of Jalan Petaling acts as the permanent overhead structure for businesses, (iii) The handbags are displayed on shelves which are fixed on site, (iv) An example of a business space similar to (ii).The premise is equipped with CCTV, fans and lights. Electricity is obtained from the shophouses, (v)These small metal kiosks have the dimension of $1500 \mathrm{~mm}(\mathrm{w}) \times 2500 \mathrm{~mm}$ (l) x $2000 \mathrm{~mm}(\mathrm{~h})$. The doors are secured with a lock to keep the merchandises safe when the business is closed, (vi) The 'wall' panels are designed to open up as awnings or be enclosed fully at the end of the business day,(vii) Street hawker with simple dining area in the alley of Lorong Petaling, (viii) An example of a stall in the wet market.
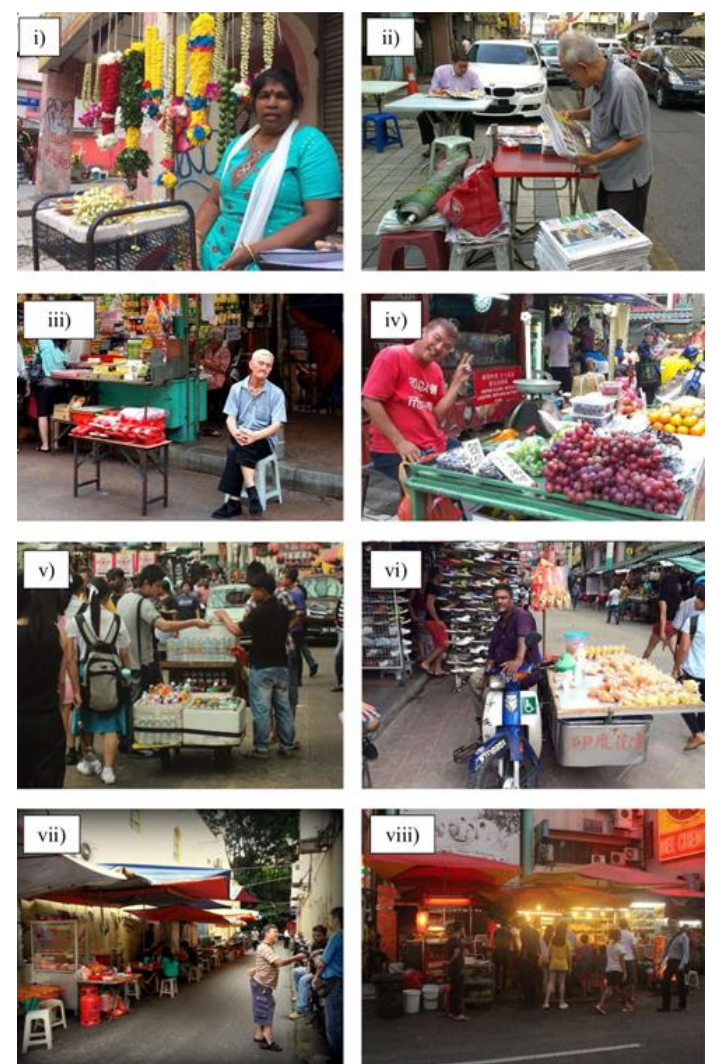

Figure 4: Examples of non-permanent structures

(i)Flower garland seller using a simple metal shelf as working table and flowers hung from a temporary pole, (ii) Evening newspaper sold from the pavement to passing cars, (iii) Elderly man selling wooden clocks from a small table, (iv) Fruits displayed on a simple table top without covering, (v) Cold drinks sold from trolleys (vi) Muruku seller from Brickfields who comes to Chinatown daily to sell the Indian titbits, (vii) Makeshift dining area in the alley off Jalan Sultan (viii) Lok lok or assorted skewers stall that is only open during dinner time.

\subsection{Variety of Choices 4.2.1 Types of items on sale}

There are a wide variety of items on retail at the Street Market which ranges from fresh produce to consumer goods as well as a wide galore of street food. At the Street Market alone, 404 businesses were involved in the retail of various goods and merchandise. The top five items traded were various types of bags (86), clothing items (78), footwear (35), watches (34) and sunglasses (22). The ability of the street traders to quickly adapt and offer items that meets the current trend, design, popular culture or latest technologies also is an attractive feature of the 
businesses found in Chinatown.

On the other hand, the wide selection of street food allures the pedestrians to stop for a meal or quench their thirst by an alley stall. There are 102 businesses in the F\&B industry, of which $46 \%$ (47) sold meals prepared on site with street side dining facilities. The majority of such food hawkers sold some form of noodle dish (18) which are mostly non-halal. The many food dishes that have become famous local delicacies have also made Chinatown a location for food lovers. The remaining 54\% (55) sold drinks (12), cut fruits (11) and other light refreshments that can be consumed on the move.

There are only $1 \%$ (8) of street traders in the service sector. Although the numbers are small in comparison to overall number of street trading activities, their presence are significant to add character to the street. These businesses includes watch repairing services, a locksmith, a cobbler, street musician, street artist and a tattoo artist. The complete list of all the items on sale are shown in Table 1.

Table 1: List of all items on sale at Chinatown Kuala Lumpur

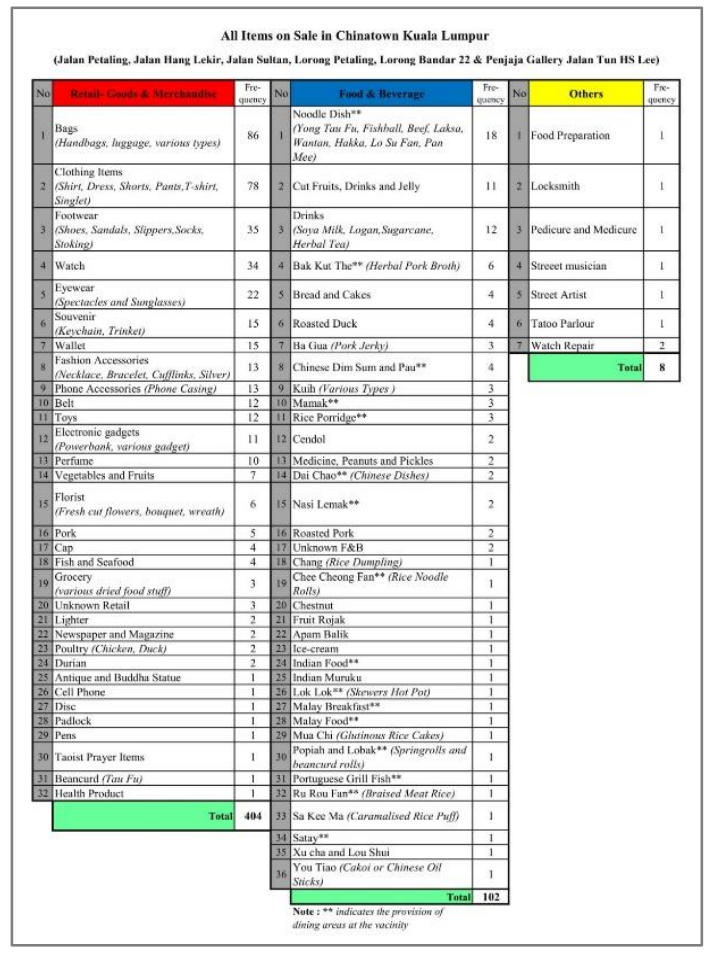

\subsubsection{Transient business setup}

The transient nature of the business setups and the informal use of space in Chinatown gives the visitor a glimpse to another side of Kuala Lumpur where the haphazardness of the site compliments the organic arrangements of the premises which comes in various shapes and sizes. Street trading activities operate from two general structure type- permanent structure 125 (23\%) and non-permanent structures 414 (76\%). There are $8(1 \%)$ of the structure type that was not reported.

Permanent structures are premises that are fixed in place and could not be removed unless it is being dismantled or demolished. Some examples of the more permanent premises are extensions from existing buildings and stalls which are built on site.

The non-permanent structures on the other hand are agile and transient. These characteristics animates the streets of Chinatown as street trading activities appears, disappears and regroups depending on their business hours. The premise typology comprises of makeshift stalls 212 (39\%), pushcart $156(29 \%)$, extension from existing buildings $18(3 \%)$ and $25(5 \%)$ premises falls under the 'other' category - tables (12), motorcycle (4), walking vendor (2), no structure (2), lorry (1), briefcase (1), box (1) and 2 are unknown.

The changes in the street density at different times of the day, characterised by the evolving layouts and patterns of structures and business types creates a variation in the atmosphere of the Street Market. This lively atmosphere, robustness of the street trading activities with something new that is on sale and something different happening at every visit in itself becomes an attraction to visit Chinatown.

\subsection{Availability of Food}

Food and drinks can be found in abundance in and around the Street Market. There are 102 street trading activities that are $\mathrm{F} \& \mathrm{~B}$ related which also translates into 1 in every 5 businesses. Street hawking is the main activity type in these three locations, where more than $80 \%$ of the businesses there are related to F\&B: Jalan Sultan (37), Lorong Petaling (16) and Lorong Bandar 22 (10). The wide pavements and sidewalks on Jalan Sultan as well as the narrow alleys of Lorong Petaling and Lorong Bandar 22 have been utilised fully for food preparation and 
outdoor dining areas, thus transforming these places clearly into outdoor food galleries. Furthermore, street food are available throughout the day from $7 \mathrm{am}$ to $11 \mathrm{pm}$ to cater to the demands of the hungry patrons.

According to the feedback received from the street hawkers, the market segment that makes up their returning customers are the people who live within the vicinity of Chinatown, office workers whose work place are in the surrounding buildings and students from the nearby schools and colleges. Apart from the convenience and many food choices, the street food remains one of the most affordable meal options especially for those who are looking for a quick bite during their lunch breaks.

This study highlights that the food culture of Chinatown has lasted the test of time where 13 of the 16 oldest running businesses over 50 years in practice are from the F\&B sector. The longest running business is the stall selling soya milk drink which was first established at the same location in 1927.

The findings further reinforces the authenticity of these family recipes as it remains the only activity type that was successfully passed down from one generation to the other, a seven fold increase from business knowledge acquired through apprenticeship. However, among family run businesses only $40(22 \%)$ claimed that their children or grandchildren will inherit the operations while another $8(4 \%)$ would be taken care of by an extended family member. The challenge in the succession of long running family businesses poses a threat to sustainability of the cultural heritage of Chinatown.

For a visitor who is keen to sample some local dishes, Chinatown serves authentic Chinese street food where local ingredients, flavours and cooking techniques can be savoured on the street. The many outdoor dining areas put informally together by plastic tables and chairs offers diners a place to sit, rest and people watch while they eat.

\subsection{Lively Outdoor Atmosphere}

The layering of various activities taking place at the street level in Chinatown undoubtedly creates a lively outdoor atmosphere in the public realm. The informal nature of the business setup provides the pedestrian an alternative shopping and dining experience that allows for the kinaesthetic sense of place.

During the operating hours, Jalan Petaling and Jalan Hang Lekir transforms into a pedestrianized outdoor bazaar with endless things to see, buy, taste and experience. The lively shopping atmosphere can also be quite chaotic as traders call out to potential customers at the top of their voices desperate to strike a deal. Bargaining for the lowest prices is also a common practice among the customers as they haggle for the best deals. The informal shopping experience and the interaction between people served as an interesting component of Street Market.

The number of pedestrian peaks during lunch hour as the back lanes and hawker stalls swells with a large hungry crowd turning the narrow alley into a noisy composition of chatter and laughter. The clanking of pots and pans followed by flavourful aroma of freshly cooked meals along the street definitely wets the appetite of the passer-by. Open air dining in simple makeshift setups remains the main dining experience at the street level.

The total number of street traders tends to vary from 149 to 161 during the day and increases to 248 at night and thus changing the street density, atmosphere and overall shopping experience. The diagram in Figure 5 illustrates the changes in the streetscape mentioned. The $5 \mathrm{pm}$ to $6 \mathrm{pm}$ timeframe remains the most exciting period as the streets around Chinatown experiences the scrambling of pushcarts as traders weaving their way through traffic to find their way to the Street Market. For the observer, this chanced observation can be quite amusing as they watch the unintentional parade of goods and businesses structures in all shapes and sizes converging quickly towards Jalan Petaling.

The kinaesthetic experience of the street through sight, smell, sound, taste and touch from the various street trading activities at Chinatown promotes the lively outdoor atmosphere of the place. 


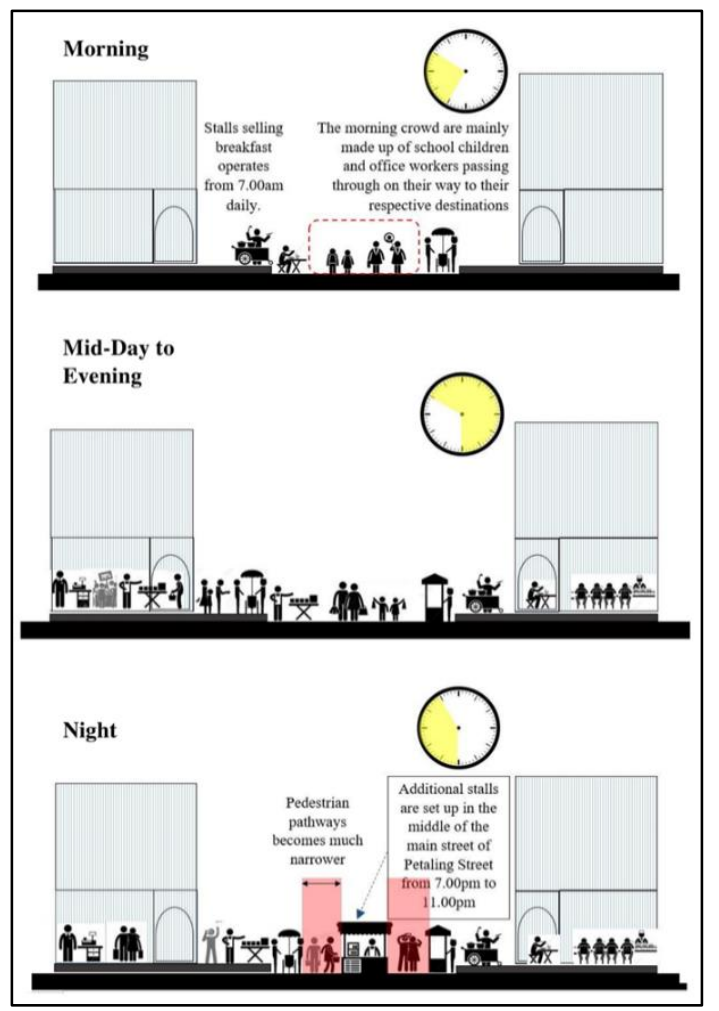

Figure 5: Changes in street density of the Street Market

\subsection{Promotes Street Walkability}

The pedestrianised shopping streets offers pedestrians a place to safely linger and leisurely browse through the many items on sale as they experience the finer grains of the city. This also encourages the interaction with street traders as well as the occasional small talk with other pedestrians, such encounters have become very rare in modern society.

The roofing structure, erected over Jalan Petaling provides shelter from the sun and rain and further encourages pedestrians to spend time strolling among the items on sale.

The active street use, high pedestrian traffic coupled with the long operating hours of the Street Market offers sense of security and safety in the city especially from the incidences of petty crimes and pickpockets. The strategic location of Chinatown situated between key transportation hubs and surrounding office buildings also acts as an avenue to connect between these spaces and further promotes walkability in the city.

\subsection{Extended Business Hours}

The street trading activities operates from as early as $7 \mathrm{am}$ and extends up to pass $10 \mathrm{pm}$ daily on every day of the year. The relatively long business hours is an advantage to the businesses as it allows for a visit during any time of the day. A visit to Chinatown at the different times of the day also permits one to experience the changing street atmosphere as the density of the street and businesses changes particularly when comparing between the day and night shopping scenes. At night, as the number of street trading activities doubles, the spatial configurations and space use also adapts to accommodate them. The extend of which Jalan Sultan is transformed into a food street at night with its sidewalks used as informal outdoor dining allows for the pedestrian to participate in becoming life on the street.

\section{CONCLUSION}

This study discovered the six characteristics that contributes and sustains the robustness of the shopping street in Chinatown Kuala Lumpur. Collectively, all six characteristics were successful in maintaining the place identity as a Street Market which is a significant feature of Kuala Lumpur's Chinese cultural and ethnic enclave. This study acknowledges that change is inevitable and quite a few obvious differences such as the types of goods on sale and the demographics of the traders which are now largely migrant workers have been seen in the recent years. Nevertheless, the essence of the place as a bustling street of commerce and the multi layered use of the public space for various activities remains as the two most authentic place identity which continues to contribute to the overall city livability.

It is imperative that the city councils, urban planners and various stakeholders realize that such spaces where the informal street trading activities are allowed to flourish can become settings where organic and authentic 'placemaking' happens. Allowing street life to happen spontaneously while celebrating a little haphazardness adds much character and excitement to the urban fabric of any city. The presence of a living community allows visitors to have a peek into the daily lives of the local community where they can learn, engage and experience the city in its peculiar and truthful nature. The case study of Chinatown Kuala Lumpur recognises the meaningful elements that 
street trading activities contributes to the city's identity, culture and history. It is the desire of this study that such characteristics be considered in the urban renewal and planning strategies of future livable cities.

\section{REFERENCES}

Alderslade, J., Talmage, J., \& Freeman, Y. (2006). Measuring the informal economyOne neighborhood at a time.

Alexander, C., Ishikawa, S., Silverstein, M., Jacobson, M., Fiksdahl-King, I., \& Angel, S. (1977). A Pattern Language. Oxford University Press.

Appleyard, D. (1981). Livable Streets : Protected Neighborhoods? The Annals of the American Academy of Political and Social Science, 451(Changing Cities: A Challenge to Planning ( Sep ., 1980 )), 106-117.

Bhowmik, S. K. (2007). Street vending in urban India: the struggle for recognition. In John Cross \& A. Morales. (Eds.), Street Entrepreneurs: People, Place, \& Politics in Local and Global Perspective (pp. 89-123). New York: Routledge.

Bogdan, R., \& Biklen, S. K. (1992). Qualitative research for education: An introduction to theory and methods. Boston: Allyn and Bacon.

Bromley, G. (2007). Foreword. In J. Cross \& A. Morales (Eds.), Street Entrepreneurs: People, Place, \& Politics in Local and Global Perspective (pp. Xv-xvii). London: Routledge.

Bromley, R. (2000). Street vending and public policy: A global review. Journal of Sociology and Social Policy, 20(1), 1-28.

Chakrabarty, B. K. (2001). Urban management: Concepts, principles, techniques, and education. Cities, 18(5), 331-45.

Chua, Y. P. (2012). Mastering Research Methods. Shah Alam: Mc Graw Hill.

Cross, J. C. (2000). Street vendors, modernity and postmodernity: conflict and compromise in the global economy. International Journal of Sociology and Social Policy, 20(1), 29-51.

Douglass, M., \& Deniere, A. (2000). The Politics of Civic Space in Asia: Building Urban Communities. Urban Studies, 37(12), 2377-2391.

Farrell, A., \& Hart, M. (1998). What Does Sustainability Really Mean?: The Search for Useful Indicators. Environment: Science and Policy for Sustainable Development, 40(9). https://doi.org/https://doi.org/10.1080/0013 9159809605096

Israt, A. S., \& Adam, M. (2017). An investigation of physical attributes relevant to the informal street hawking in the urban spaces of Dhaka city. Journal of Design and Built Environment, 17(1), 75-86. https://doi.org/10.22452/jdbe.vol17no1.5

Jacobs, J. (1961). The Death and Life of Great American Cities. London: Penguin Books. https://doi.org/10.2307/794509

Loo, Y. M. (2013). Architecture and Urban Form in Kuala Lumpur: Race and Chinese Spaces in a Postcolonial City. Surrey: Ashgate Publishing Limited.

Lyon, F. (2007). Institutional perspectives on understanding street retailer behaviour and networks. In J. Cross \& A. Morales (Eds.), Street Entrepreneurs: People, Place, \& Politics in Local and Global Perspective (pp. 164-179). London: Routledge.

Maxwell, J. A. (2012). Qualitative Research Design: An Interactive Approach. Thousand Oaks, London New Delhi: SAGE Publications.

McGee, T. G., \& Yeung, Y. M. (1977). Hawkers in Southeast Asian cities: Planning for the bazaar economy. Ottawa, Canada: International Development Research Center.

Oldenburg, R. (1989). The Great Good Public Place :Cafes, Coffee Shops, Bookstores, Bars, Hair Salons, and Other Hangouts at the Heart of a Community. New York: Da Capo Press.

Oranratmanee, R. (2012). The Use of Public Space for Pedestrian Streets in Thailand.

Oranratmanee, R., \& Sachakul, V. (2014). Streets as Public Spaces in Southeast Asia: Case Studies of Thai Pedestrian Streets. Journal of Urban Design, 19(2), 211-229. https://doi.org/10.1080/13574809.2013.870 465

Packard, T. G. (2014). Do Workers in Chile Choose Informal Employment? A Dynamic Analysis of Sector Choice, (May). https://doi.org/10.1596/1813-9450-4232

Pillai, J. (2013). Cultural Mapping - A Guide to Understanding Place, Community and Continuity (1st Editio). Petaling Jaya: Strategic Information and Research Developement Centre. 
Recio, R. B., \& Gomez, J. E. A. (2013). Street vendors, their contested spaces, and the policy environment: A view from caloócan, Metro Manila. Environment and Urbanization ASIA, 4(1), 173-190. https://doi.org/10.1177/0975425313477760

Shamsuddin, S., Sulaiman, A. B., Norhaslina, J., \& Maslyana, M. (2004). Criteria of success for traditional shopping streets in Malaysia: Case study of Kuala Lumpur. Un published Research Report.

Shamsuddin, Shuhana. (2011). Townscape Revisited: Unravelling the Character of the Historic Townscape in Malaysia. (R. Razali, Ed.) (1st Editio). Penerbit UTM Press.

Shamsuddin, Shuhana, \& Sulaiman, A. B. (2001). The Vanishing Streets in the Malaysian Urbanscape. Public Places in Asia Pacific Cities, 60, 137-149. https://doi.org/https://doi.org/10.1007/97894-017-2815-7_7

Shamsuddin, Shuhana, \& Ujang, N. (2008). Making places: The role of attachment in creating the sense of place for traditional streets in Malaysia. Habitat International, 32(3), 399-409. https://doi.org/10.1016/j.habitatint.2008.01. 004

Shuhana Shamsuddin, N. U. (2008). Making places: The role of attachment in creating the sense of place for traditional streets in Malaysia. Habitat International, 32, 400409.

https://doi.org/10.1016/j.sbspro.2012.12.23 3

Sun, Z., Bell, S., \& Scott, I. (2016). How Does Street Vending Contribute to Walkability? A report on a study in Yuncheng, China. Environment-Behaviour Proceedings Journal, 203. https://doi.org/10.21834/e-bpj.v1i4.166

Whyte, W. H. (1980). The social life of small urban spaces. Santa Monica, CA: Direct Cinema Ltd. 